\title{
Research on the Deformation Mechanism and Directional Blasting Roof Cutting Control Measures of a Deep Buried High-Stress Roadway
}

\author{
Xiaojie Yang, ${ }_{1}^{1}$ Chenkang Liu $\mathbb{D},{ }^{2}$ Honglei Sun, ${ }^{1}$ Songlin Yue $\mathbb{D},{ }^{3}$ Yuguo Ji, ${ }^{2}$ Xingyu Zhang, \\ and Lin Hou ${ }^{1}$ \\ ${ }^{1}$ State Key Laboratory for Geomechanics \& Deep Underground Engineering, China University of Mining \& Technology, \\ Beijing 100083, China \\ ${ }^{2}$ School of Mechanical Engineering, Nanjing University of Science and Technology, Nanjing 210094, China \\ ${ }^{3}$ State Key Laboratory for Disaster Prevention \& Mitigation of Explosion \& Impact, College of Defense Engineering, \\ Army Engineering University of PLA, Nanjing 210007, China \\ Correspondence should be addressed to Chenkang Liu; chenkang_liu@163.com and Songlin Yue; yslseu@hotmail.com
}

Received 29 October 2019; Revised 8 July 2020; Accepted 16 July 2020; Published 30 July 2020

Academic Editor: Yuri S. Karinski

Copyright ( $\odot 2020$ Xiaojie Yang et al. This is an open access article distributed under the Creative Commons Attribution License, which permits unrestricted use, distribution, and reproduction in any medium, provided the original work is properly cited.

\begin{abstract}
Affected by the mining activities of the working face, the surrounding rock of the roadway is easily deformed and destroyed. For deep buried roadways, the deformation and destruction of the surrounding rock is particularly prominent. Under the influence of in situ stress fluctuation, $3^{-1} 103$ tailgate of the Hongqinghe coal mine was in a complex stress environment with a maximum stress exceeding $20 \mathrm{MPa}$. Affected by mining stress, the roadway behind the working face was seriously deformed. In order to alleviate the deformation of the roadway, directional blasting and cutting measures for the $3^{-1} 103$ tailgate were adopted in this paper. The mechanism of crack propagation in single-row to three-hole directional blasting was revealed by numerical simulation. The blasted rock was divided into three regions according to the crack condition. The numerical analysis of the cutting heights of $0 \mathrm{~m}$, $10 \mathrm{~m}, 12 \mathrm{~m}$, and $14 \mathrm{~m}$, respectively, showed the stress peaks of different cutting heights and the deformation law of the surrounding rock. The pressure relief effect was the best at $14 \mathrm{~m}$ cutting height. At this time, the peak stress was $39 \mathrm{MPa}$ with the smallest roadway deformation. Based on numerical simulation and theoretical analysis results, engineering tests were carried out. Field monitoring showed that the deformation of the roadway was inversely proportional to the roof cutting height. The higher the cutting height is, the more preferential the roadway is to reach the stable state. It can be concluded that directional blasting can change the surrounding rock structure, control the deformation of the roadway, and play a role in pressure relief. It provides a new measure to control roadway deformation.
\end{abstract}

\section{Introduction}

As the key channel of the coal mine production system, roadway stability is one of the key factors to achieve high production and efficiency. In the process of roadway excavation and working face mining, the phenomenon of roadway floor heave and rock burst is often accompanied. Especially after reaching deep mining, this kind of phenomenon becomes increasing prominent [1-3].

Experts and scholars have carried out relevant research on the deformation mechanism and control measures of the surrounding rock of a deep roadway. Li et al. obtained the main mineral composition and water absorption characteristics of the surrounding rock through rock mechanics experiment and the X-ray diffraction test and revealed the deformation mechanism of the roadway [4-7]. Wang et al. [8] established a static model based on the relationship between the stress state and volume change of the surrounding rock and revealed the phenomenon of zonal failure of the surrounding rock in a deep roadway. Yuan et al. [9] established the mechanical model of a circular roadway under a deep dynamic pressure environment and analyzed 
the evolution law of plastic zone. Chen et al. [10] studied the incompatible deformation of a dynamic pressure roadway. It was concluded that the deformation and failure of the dynamic pressure roadway were mainly affected by the mining stress, surrounding rock characteristics, tectonic stress, and overlying strata pressure.

Only by understanding the deformation and failure mechanism of a roadway can reasonable control measures be taken to effectively control and maintain the deformation of the roadway. The common methods to control the deformation of the surrounding rock are strengthening support and pressure relief treatment. Wang et al. [11] put forward the concept of "integral support" and developed the support system of square steel restrained concrete. In view of the large deformation of the surrounding rock roadway in Du'erping coal mine, Yang et al. [12] put forward a new "shell + anchor + shotcrete" combined support structure. According to the deformation characteristics of a soft rock roadway, Guo et al. [13] studied the interaction mechanism between a new type of bolt (constant resistance large deformation bolt) and the surrounding rock. Yang et al. [14] used a numerical calculation method to reveal the deformation characteristics and crack propagation mechanism of the surrounding rock of a deep soft rock roadway and proposed the support scheme of "bolt-cable-mesh + shell." Aiming at the problem of large deformation of a soft rock roadway, Yang et al. [15] developed a U-steel set with a roof + floor beam + braces set. In order to meet the requirements of green mining and prevent mine pressure disaster, Mu et al. [16] proposed a novel segmented roadside plugging-filling mining method.

Reinforcement and support of the roadway can control the deformation of the surrounding rock effectively. However, it has not fundamentally eliminated the influence of mining pressure on the surrounding rock, which is a "passive" measure. Only by eliminating the influence of mining pressure from the root can the deformation of surrounding rock be controlled. Chen et al. [17] used shallow-hole blasting to relieve pressure on the side roof of a gob-side roadway. The deformation of the roadway was controlled. Also, the stability of the roadway along the gob was maintained. Qi [18] put forward the comprehensive pressure relief technology of deep hole presplitting blasting, pressure relief roadway, and coal seam borehole pressure relief, which can improve the stress condition of the roadway surrounding rock and reduce the stress concentration factor.

Professor $\mathrm{He}$ et al. proposed the roof cutting and pressure relief gob-side entry and retention technology based on the short arm beam theory in 2008 [19-21]. Subsequently, Professor He's team carried out field test research on roof cutting and pressure relief gob-side entry and retention technology under different geological conditions. Ma et al. [22-24] carried out presplitting blasting on the roof, which alleviated the stress distribution along the gob roadway effectively. In order to solve the problem of roadway deformation, Yang et al. [25] proposed the method of "roof cutting and pressure relief of an adjacent roadway" based on "roof cutting short wall beam" and obtained the optimal blasting roof cutting scheme through the theoretical analysis and field test. A no-pillar mining technique with automatically formed gob-side entry retaining was proposed for longwall mining and roadway deformation [26]. Wang et al. [27] proposed a liquid directional cutting technology instead of blasting roof cutting to solve the problem of pressure relief in blasting roof cutting. To solve the problem of deformation and failure of a dynamic pressure roadway, Yang et al. [28] obtained the technical scheme of blasting pressure relief suitable for a dynamic pressure roadway through a theoretical analysis, numerical calculation, and industrial test. A method for the automatic formation of roadways in deep mining areas by roof cutting with high-strength bolt-grouting was proposed by Wang et al. [29].

In this paper, directional blasting technology was applied to the condition of roof cutting and pressure relief of a deep high-stress dynamic pressure roadway. Through the field observation and test, the deformation characteristics and mechanism of the roadway were obtained. A mechanical model for roof cutting and pressure relief in directional blasting were proposed. The crack propagation and zoning phenomena in directional blasting were obtained by numerical simulation. The numerical model of roof cutting of a deep buried high-stress roadway was established. The stress distribution and surrounding rock deformation of the roadway under different roof cutting heights were obtained. A field case study in the Hongqinghe coal mine was also presented to validate the numerical results.

\section{Engineering Background}

2.1. Production Geological Conditions. The Hongqinghe coal mine is located in Inner Mongolia, China. This mine produces approximately 15 million tons of coal annually. The selected panel ( $3^{-1} 101$ mining panel) is approximately $245 \mathrm{~m}$ wide and $3212 \mathrm{~m}$ long, with a dip angle of less than $3^{\circ}$. The mean thickness of the coal seam is $6.36 \mathrm{~m}$ with an average overburden. The mine location and layout of the mining panel are shown in Figure 1. The column map of the stratum is shown in Figure 2.

\subsection{Deformation Characteristics of a Deep Buried High-Stress} Roadway. The $3^{-1} 103$ tailgate belongs to a typical large section coal roadway with a section area of $20.0 \mathrm{~m}^{2}$. Before mining activities in the $3^{-1} 101$ mining panel, under the action of original rock stress, the coal wall had been seriously damaged in the process of excavation. As shown in Figures 3(a) and 3(b), cracks were developed in the coal wall and swelling occurred in the middle of the roadway side. The integrity of the coal wall was poor.

Influenced by mining activities, the floor cracked and heaved up at about $30 \mathrm{~m}$ ahead of the working face in some areas. In the area behind the working face, the deformation of the roadway increased and the bolt was broken, as shown in Figures 3(c) and 3(d). In some areas, the maximum deformation of the two sides reached about $1.0 \mathrm{~m}$, which affected the normal transportation and pedestrians, causing serious potential safety hazards. 


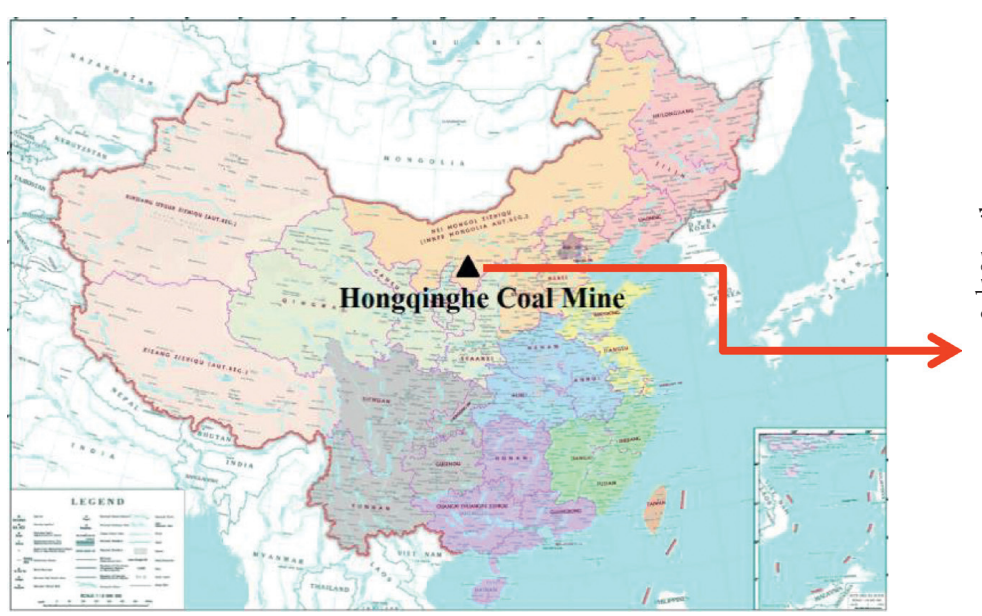

(a)

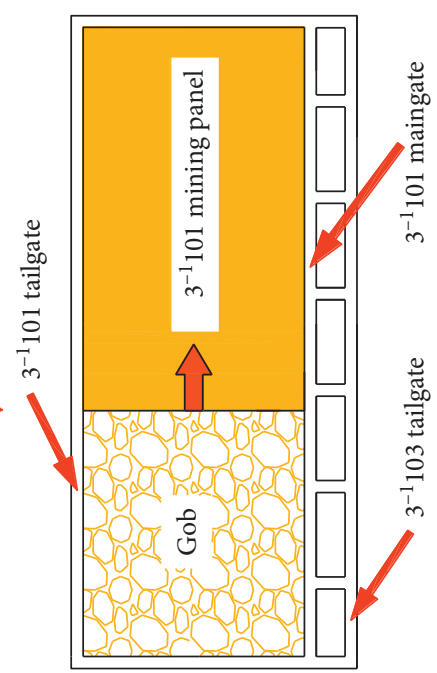

(b)

Figure 1: Coal mine location and roadway layout: (a) location of the coal mine; (b) layout of mining panel.

\begin{tabular}{|c|c|c|c|}
\hline $\begin{array}{l}\text { Thickness } \\
\text { (m) }\end{array}$ & Columnar & Lithology & Remarks \\
\hline 9.28 & & Middle conglomerate & \multirow{3}{*}{ Main roof } \\
\hline 0.29 & & Fine conglomerate & \\
\hline 7.80 & & Fine grained sandstone & \\
\hline 7.84 & & Siltstone & \multirow{2}{*}{ Immediate roof } \\
\hline 5.20 & & Sandy mudstone & \\
\hline 6.36 & & Coal & $3^{-1}$ coal seam \\
\hline 8.58 & & Sandy mudstone & Immediate floor \\
\hline 18.20 & & Siltstone & Main floor \\
\hline
\end{tabular}

Figure 2: Column map of the stratum.

It could be concluded that secondary surrounding rock deformation occurred in the $3^{-1} 103$ tailgate due to mining activity in the $3^{-1} 101$ mining panel. The roadway floor was warped and cracked, and the bolt was broken. The deformation of the surrounding rock was greatly increasing compared with that before. Therefore, mining stress was also one of the important factors affecting the deformation of the roadway. In order to compare and analyze the deformation law of roadways before and after mining, measuring points were arranged in the $3^{-1} 103$ tailgate to monitor the deformation of the roadway.

The deformation trend of the surrounding rock can be seen in Figure 4. According to the deformation law of the surrounding rock, the deformation curve was divided into three regions (I, II, and III). The area I ranged from $50 \mathrm{~m}$ to $100 \mathrm{~m}$ ahead of the working face. At this time, the roadway began to undergo minor deformation, which was called the "initial deformation area." The area from $100 \mathrm{~m}$ behind the working face to $50 \mathrm{~m}$ ahead of the working face was zone II. Within this range, the amount of deformation of the surrounding rock increased sharply, which was called the "serious deformation zone." The deformation of the coal wall increased linearly with a maximum of $570 \mathrm{~mm}$. The floor heave was slightly larger than the roof subsidence, $317 \mathrm{~mm}$ and $192 \mathrm{~mm}$, respectively. The area after $100 \mathrm{~m}$ of the working face was area III. In this area, the deformation of the surrounding rock was slow and, finally, kept a certain value, no longer changing. It was called the "deformation stability zone." From the curve, it can be seen that the deformation of the coal wall, floor heave, and roof was $737 \mathrm{~mm}, 394 \mathrm{~mm}$, and $240 \mathrm{~mm}$, respectively.

\section{Pressure Relief Technology of Directional Blasting Roof Cutting}

3.1. Roof Cutting Pressure Relief Technology. The immediate roof will be cut off completely after presplitting blasting. Under the action of the overlying strata pressure, the main roof breaks from the precrack cutting joint. Also, the crack extends. Finally, the main roof breaks outside the coal pillar, forming a simply supported structure [30].

The main roof breaks along the precracking slit (outside of the coal pillar). The precracking slit prevents the development of cracks in coal pillars and roadway effectively and avoids the impact damage of main roof collapse on the pillar and roadway. The roof structure between the gob and coal 


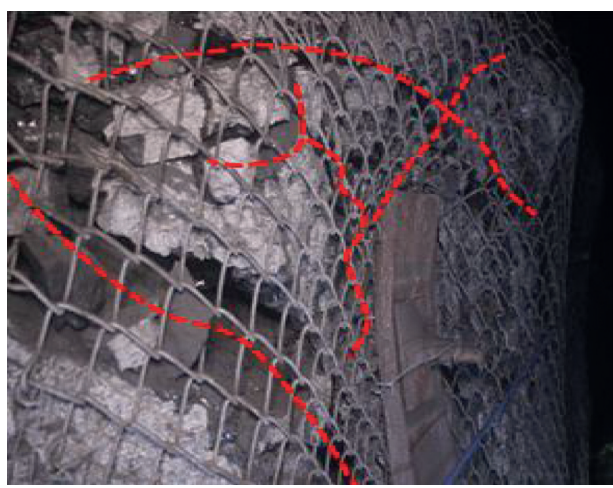

(a)

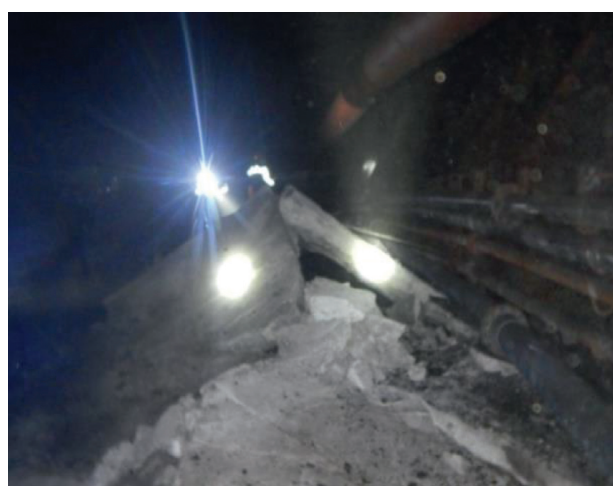

(c)

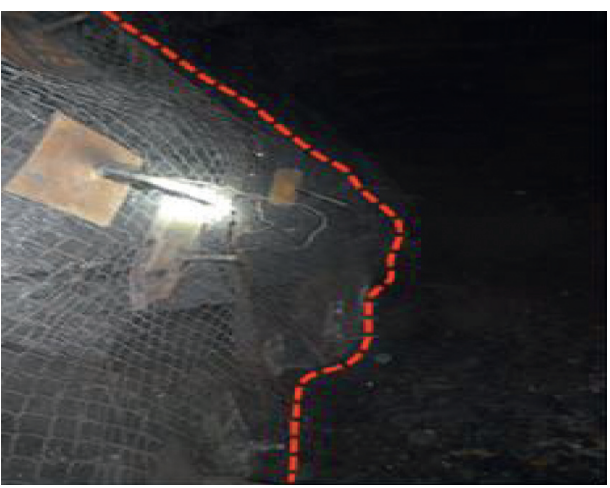

(b)

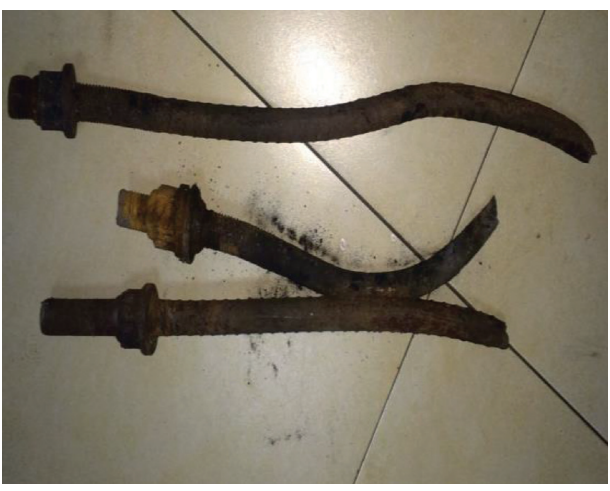

(d)

Figure 3: Roadway deformation: (a) coal wall cracks; (b) coal wall bulging; (c) floor warping and cracking; and (d) broken bolt.

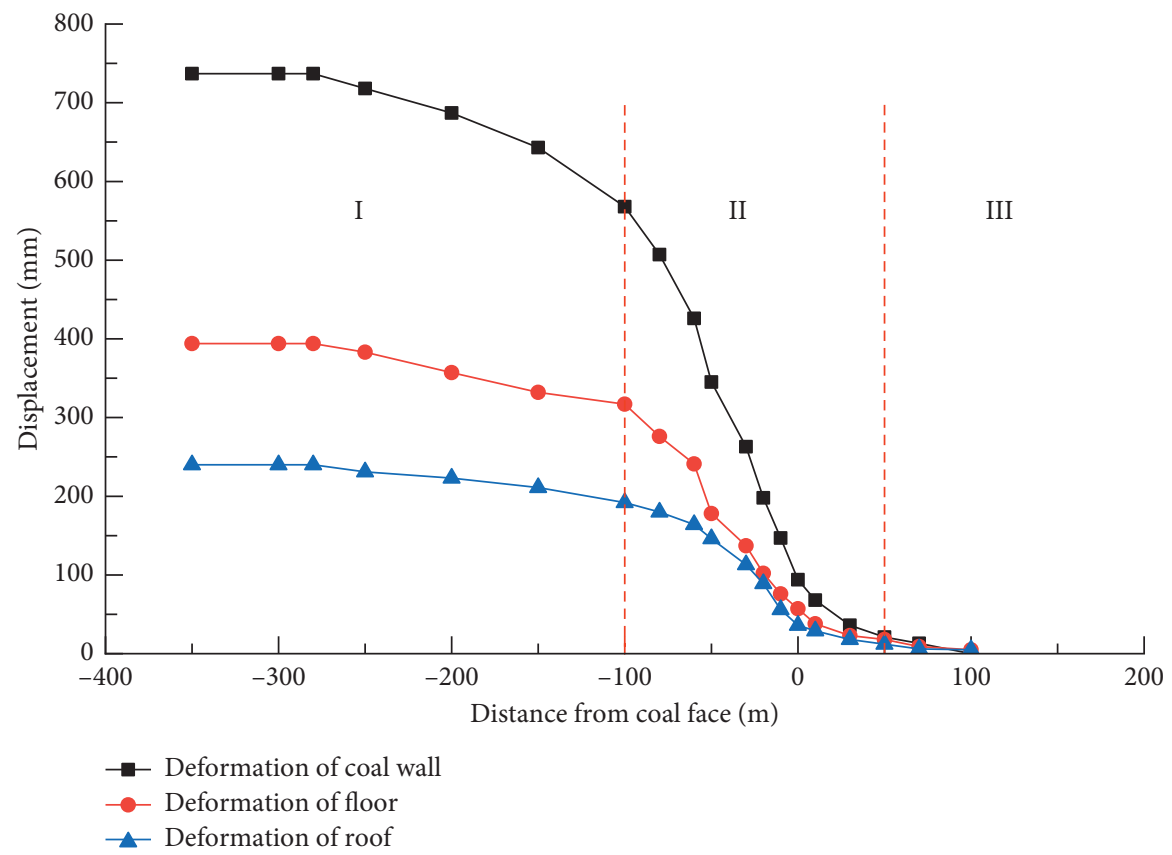

FIgURE 4: Deformation of the surrounding rock.

pillar has been cut off by the precracking slit. This makes the roof change from a long cantilever to a short wall beam structure with a cut roof, which destroys the energy storage condition of the roof, as shown in Figure 5. According to the "key strata theory" [31, 32], the overlying strata will collapse synchronously with the advancing of the working face and the efficiency of roof collapse enhanced by roof cutting. The collapsed gangue fills the gob and plays a supporting role on 


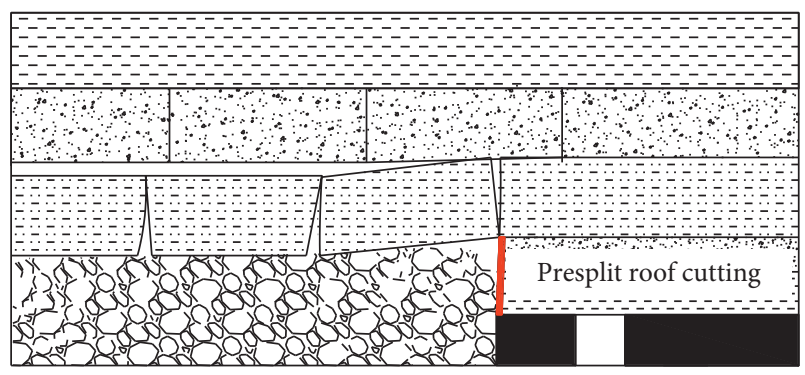

FIgURE 5: Structural model of roof cutting.

the roof. Thus, the stress transfers to the side of gob, which alleviates the influence of roof pressure on the side pillar and roadway. After cutting the roof, the pressure of the coal pillar is released, and the stress concentration of the roadway is also reduced.

\subsection{Numerical Analysis of Directional Blasting.} Directional blasting can realize the shaping blasting in a specified direction, as shown in Figure 6. It is an effective way to cooperate with mine roof cutting and pressure relief in the recent years [33-35]. Explosive detonated in the energy accumulator. The initial damage of the borehole wall occurred in the given direction. Under the action of stress wave, the crack expands continuously and achieves the directional fracture effect.

Taking the charge profile of shaped charge blasting as the calculation object, a plane stress model was established. A single-layer grid was used for calculation. The air and rock regions in the model were rectangular in size of $2000 \mathrm{~mm} \times 1000 \mathrm{~mm}$. The model size of the energy accumulator was the same as that of the actual project. Also, the parameters were as follows: internal diameter $36 \mathrm{~mm}$, external diameter $42 \mathrm{~mm}$, slit width $4 \mathrm{~mm}$, and explosive diameter $35 \mathrm{~mm}$. The diameter of the blast hole was $48 \mathrm{~mm}$, and the distance between adjacent boreholes was $500 \mathrm{~mm}$. In order to intuitively judge the failure and crack propagation of rock, an HJC material model was applied to simulate rock. Multimaterial ALE algorithm was used in the simulation. The explosion numerical simulation parameters are shown in Tables 1-3.

As shown in Figure 7(a), the initial damage of all three blast holes occurred in the direction of energy accumulation at 5 us. Under the action of stress wave, the damage range of the blast holes increased and symmetrical notches formed on both sides of the blast holes. The crack bifurcated at 60.5 us, as shown in Figure 7(b). The stress waves of adjacent blast holes were superimposed for the first time, and the effective stress in the middle of adjacent blast holes increased. Until this moment, the effective stress field was regular and symmetrical. Under the action of the blasting stress wave, the damage area expanded continuously with small cracks extending outward. At 164 us, the cracks between adjacent blast holes penetrated to achieve a directional fracture effect, as shown in Figure 7(c). In Figure 7(d), the directional crack extended outward to the model boundary with bifurcating at 479 us.

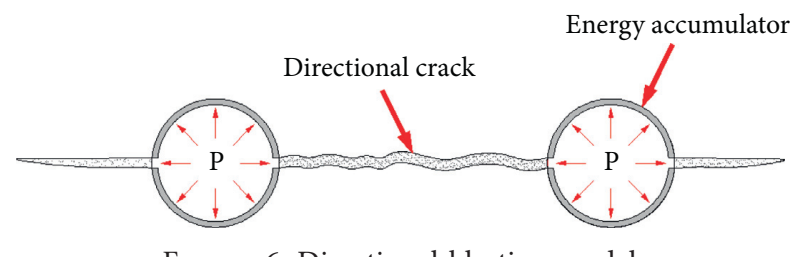

TABLE 1: Explosive parameters.

\begin{tabular}{lccccc}
\hline$\rho\left(\mathrm{g} \cdot \mathrm{cm}^{-3}\right)$ & $D\left(\mathrm{~m} \cdot \mathrm{s}^{-1}\right)$ & $A$ & $B$ & $R_{1}$ & $R_{2}$ \\
\hline 0.88 & 5170 & 3.26 & $1.82 E-3$ & 4.20 & 0.90 \\
\hline
\end{tabular}

TABLE 2: Air parameters.

\begin{tabular}{lcc}
\hline$\rho\left(\mathrm{g} \cdot \mathrm{cm}^{-3}\right)$ & $C_{4}$ & $C_{5}$ \\
\hline $1.29 E-3$ & 0.04 & 0.04 \\
\hline
\end{tabular}

3.3. Analysis of Crack Characteristics in Directional Blasting. According to the failure and crack propagation of the blast holes in numerical calculation, the rock was divided into three regions (I, II, and III), as shown in Figure 8. In region I, three blast holes were obviously damaged, and cracks of a certain width appeared on both sides of three blast holes. This region was called the "blast hole damage zone," and its width was about 3-4 times the diameter of the blast hole. Zone II was called the "crack penetration zone." In this zone, the cracks between adjacent blast holes developed and converged to achieve a directional fracture effect. The cracks between adjacent blast holes did not intersect in a straight line, but slightly moved up and down. Zone III was a "unilateral crack growth zone," which was not affected by stress wave superposition. Therefore, the crack extended along the horizontal direction. The area of the region (I, II, and III) accounted for $35.64 \%, 22.28 \%$, and $42.08 \%$ of the surrounding rock, respectively.

\section{Numerical Simulation of Roof Cutting in a Deep Buried High-Stress Roadway}

4.1. Model Building. The model adopted the Mohr-Coulomb criterion and null element to simulate face excavation. As shown in Figure 9, the model has the length of $340 \mathrm{~m}$, the width of $1 \mathrm{~m}$, and the height of $104 \mathrm{~m}$. According to the geological borehole map, the rock layers were siltstone, sandy mudstone, $3^{-1}$ coal, sandy mudstone, siltstone, fine-grained sandstone, medium conglomerate, and finegrained sandstone from the bottom to top, as shown in Figure 10. The front and back boundaries and left and right boundaries of the numerical model were constrained. There was no constraint on the upper surface of the model. Uniform load was applied to the upper surface equivalent to the dead load of the overlying strata. According to the buried depth of rock strata, the vertical uniform load of $18 \mathrm{MPa}$ could be applied. All constraints were imposed on the 
TABle 3: The material parameters of HJC [36].

\begin{tabular}{lccccccccccccccccccccccc}
\hline$\rho\left(\mathrm{g} \cdot \mathrm{cm}^{-3}\right)$ & $G(\mathrm{~Pa})$ & $A$ & $B$ & $C$ & $N$ & $f_{c}(\mathrm{~Pa})$ & $T(\mathrm{~Pa})$ & EPS0 & EFMIN & SFMAX & $P_{c}(\mathrm{~Pa})$ & $\mu_{c}$ & $p l(\mathrm{~Pa})$ & $\mu_{l}$ & $D_{1}$ & $D_{2}$ & $K_{1}(\mathrm{~Pa})$ & $K_{2}(\mathrm{~Pa})$ & $K_{3}(\mathrm{~Pa})$ & $f_{s}$ \\
\hline 2.471 & $11.67 E 9$ & 0.79 & 1.60 & 0.007 & 0.61 & $130 E 6$ & $7.07 E 6$ & $1 E-6$ & 0.005 & 4.00 & $43.30 E 6$ & 0.00278 & 1 & $E 9$ & 0.1 & 0.045 & 1.0 & 86.00 & $E 9$ & $-171.00 \mathrm{E} 9$ & 208.00 & $E 9$ & 0.04 \\
\hline
\end{tabular}

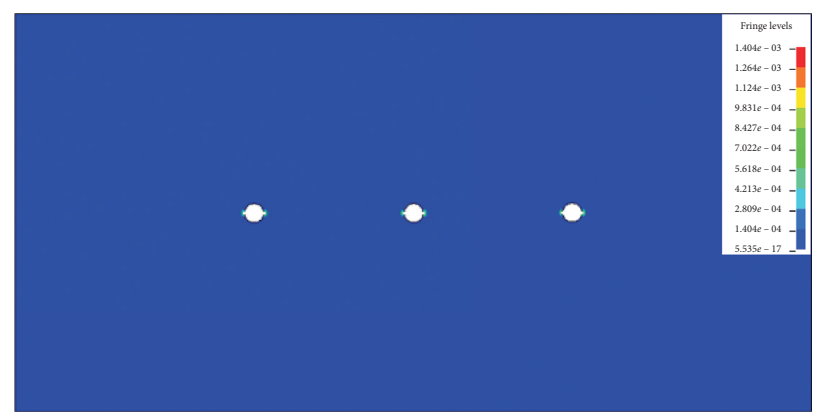

(a)

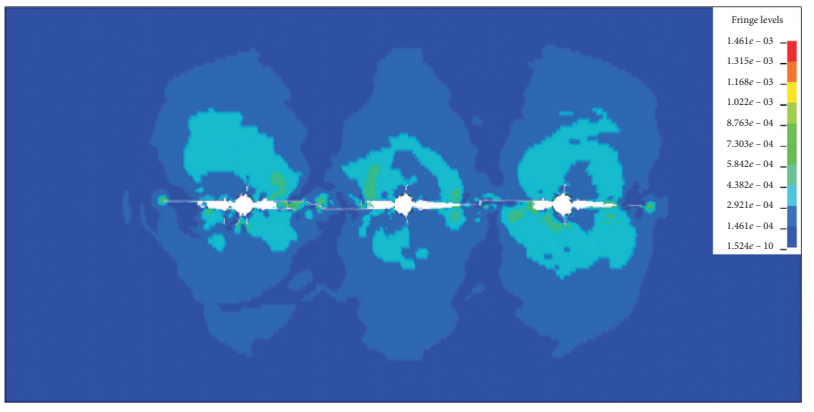

(c)

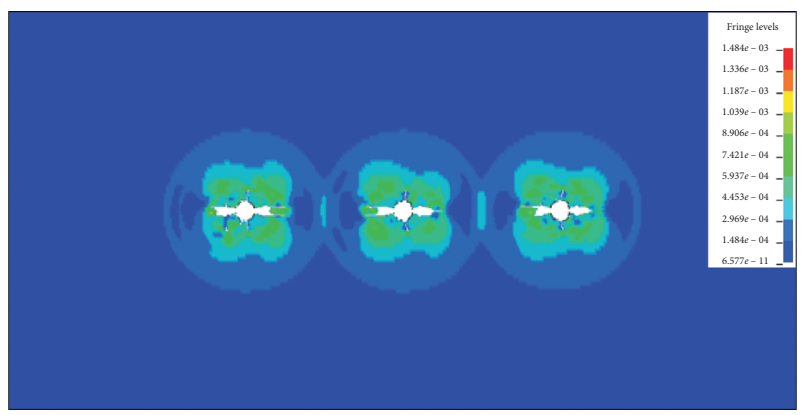

(b)

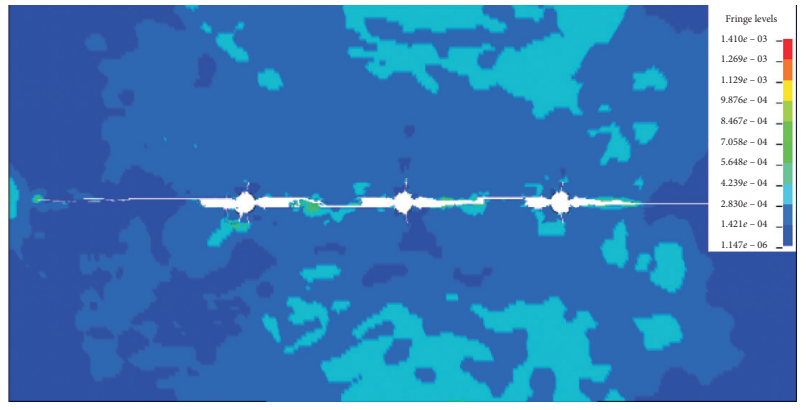

(d)

FIgURE 7: Effective stress distribution of three-hole directional fracture blasting. (a) $t=5 \mathrm{us}$; (b) $t=60.5$ us; (c) $t=164$ us; and (d) $t=479$ us.

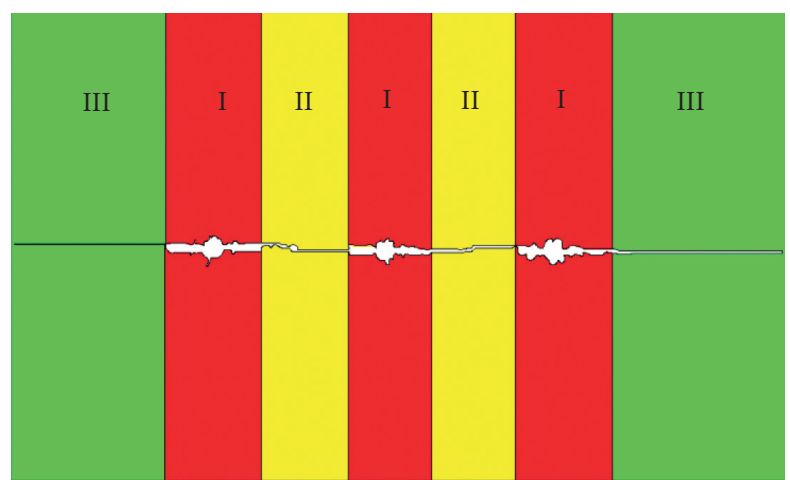

FIGURE 8: Crack zoning of blasted rock.

bottom of the model. The rock model parameters are shown in Table 4.

In engineering practice, the cutting height affected the pressure relief effect. An appropriate cutting height was the key to cut stress transfer and controlling surrounding rock deformation [37, 38]. According to the theoretical formula [39], four schemes of $0 \mathrm{~m}, 10 \mathrm{~m}, 12 \mathrm{~m}$, and $14 \mathrm{~m}$ height of roof cutting were selected to simulate to characterize the effect of roof cutting.

$$
H=\frac{\left(H_{C}-\Delta H_{1}-\Delta H_{2}\right)}{K-1} \text {. }
$$

In the formula, $H_{C}$ denotes the coal seam thickness, $\Delta H_{1}$ denotes the roof subsidence, $\Delta H_{2}$ denotes the floor heave deformation, and $K$ denotes the crushing expansion coefficient.

\subsection{Analysis of Simulation Results}

4.2.1. Stress Distribution of the Surrounding Rock. When the working face was mined, the overlying strata moved downward. The overlying strata in the gob undergo bent deformation. The stress field of the working face was continuous when the cutting height was $0 \mathrm{~m}$. With the 


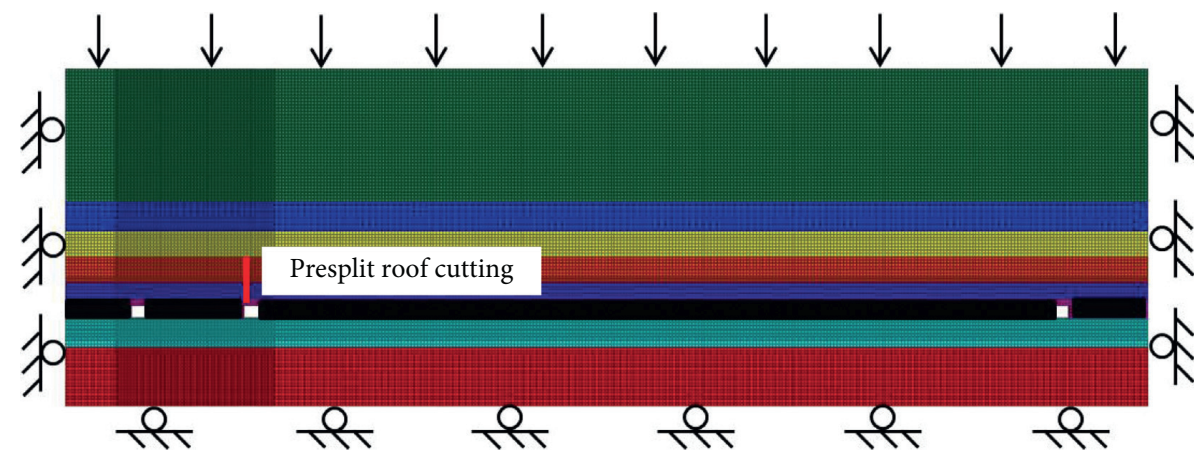

Figure 9: Numerical model.

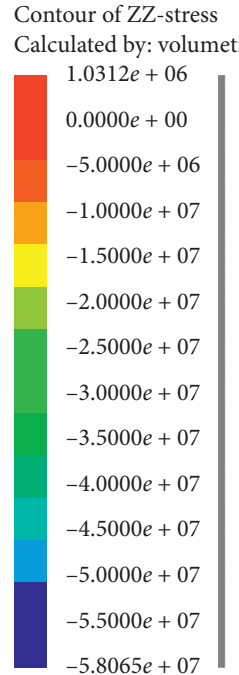

Contour of ZZ-stress

Calculated by: volumetric averaging

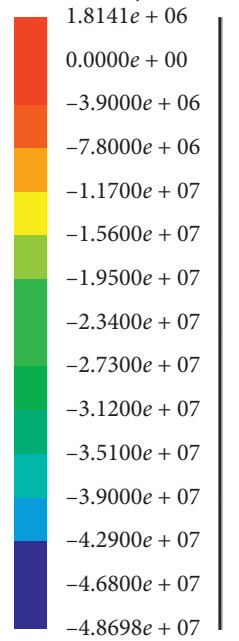

$-4.8698 e+07$

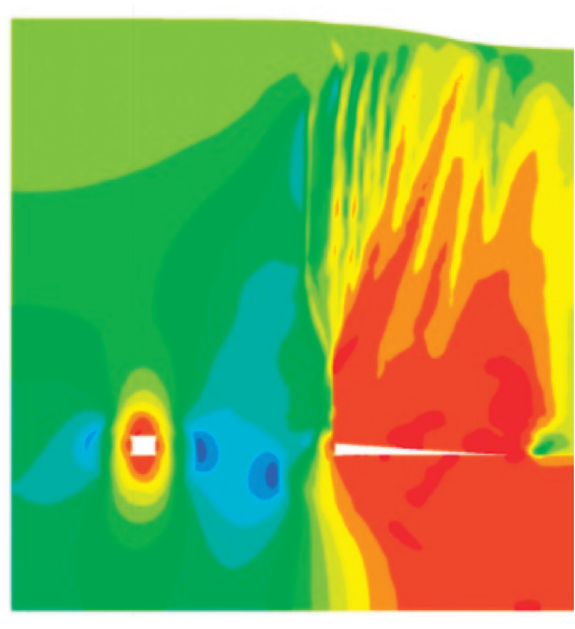

(c)

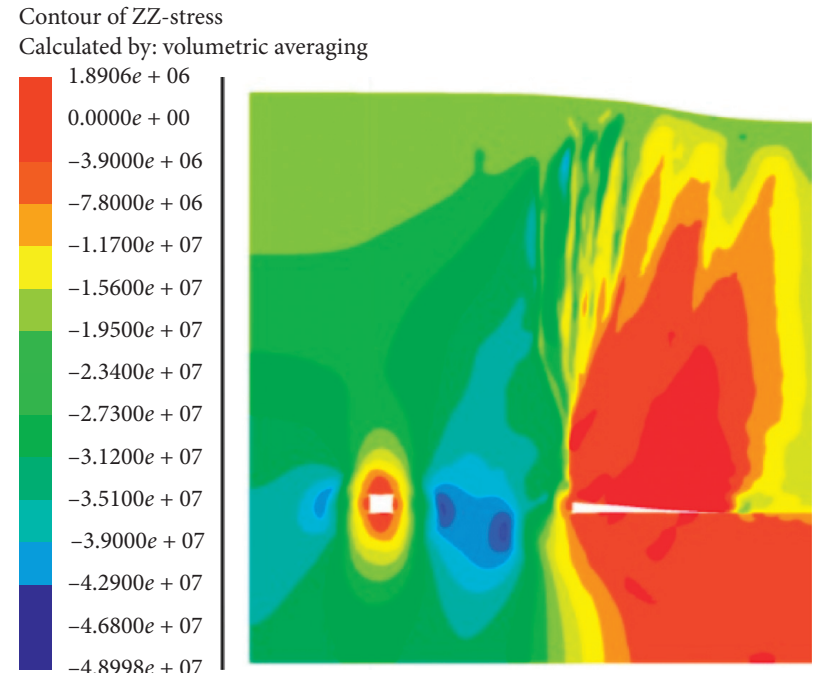

(b)

Contour of ZZ-stress

Calculated by: volumetric averaging

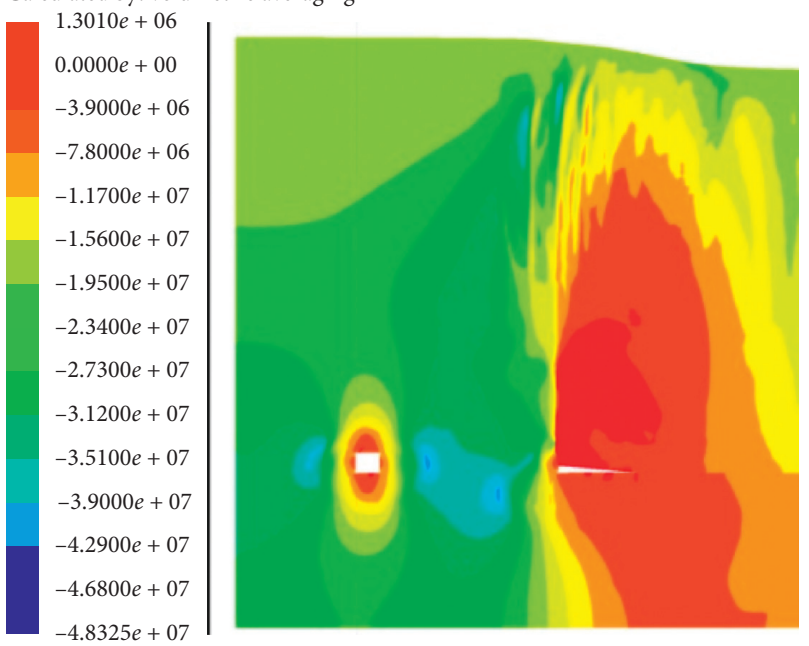

(d)

FIgURE 10: Z-directional stress: (a) cutting height $0 \mathrm{~m}$; (b) cutting height $10 \mathrm{~m}$; (c) cutting height $12 \mathrm{~m}$; and (d) cutting height $14 \mathrm{~m}$.

subsidence of the working face, the coal pillar was squeezed. The stress concentration occurred in the surrounding rock of the coal pillar. As shown in Figure 10(a), the stress concentration area was located in the middle part of the coal pillar, and the maximum vertical stress reached $58.06 \mathrm{MPa}$. Vertical pressure far exceeded the yield strength of the coal seam. The coal pillar was damaged, threatening the stability of the roadway seriously. At the same time, the stress 
TABle 4: Modeling parameters of rock.

\begin{tabular}{lccccc}
\hline Lithology & Density $\left(\mathrm{kg} / \mathrm{m}^{3}\right)$ & Bulk modulus $(\mathrm{GPa})$ & Tensile strength $(\mathrm{MPa})$ & Cohesion $(\mathrm{MPa})$ & Internal friction angle $\left(^{\circ}\right)$ \\
\hline Fine-grained sandstone & 2560 & 18 & 3.37 & 1.04 & 37.49 \\
Medium conglomerate & 2340 & 15 & 7.10 & 1.06 & 30.95 \\
Fine-grained sandstone & 2200 & 13 & 2.06 & 1.84 & 32.14 \\
Siltstone 1 & 2560 & 20 & 1.32 & 2.30 & 37.03 \\
Sandy mudstone 1 & 2340 & 13.5 & 1.06 & 2.84 & 30.61 \\
Coal & 2200 & 23 & 7.10 & 2.36 & 32.14 \\
Sandy mudstone 2 & 2340 & 14 & 1.68 & 2.50 & 30.95 \\
Siltstone 2 & 2610 & 14.7 & & 37.28 \\
\hline
\end{tabular}

Contour of

Z-displacement

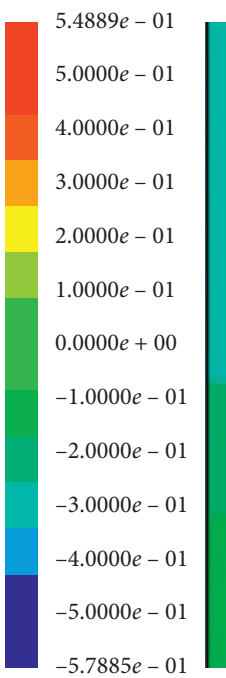

$-5.7885 e-01$

Contour of

Z-displacement

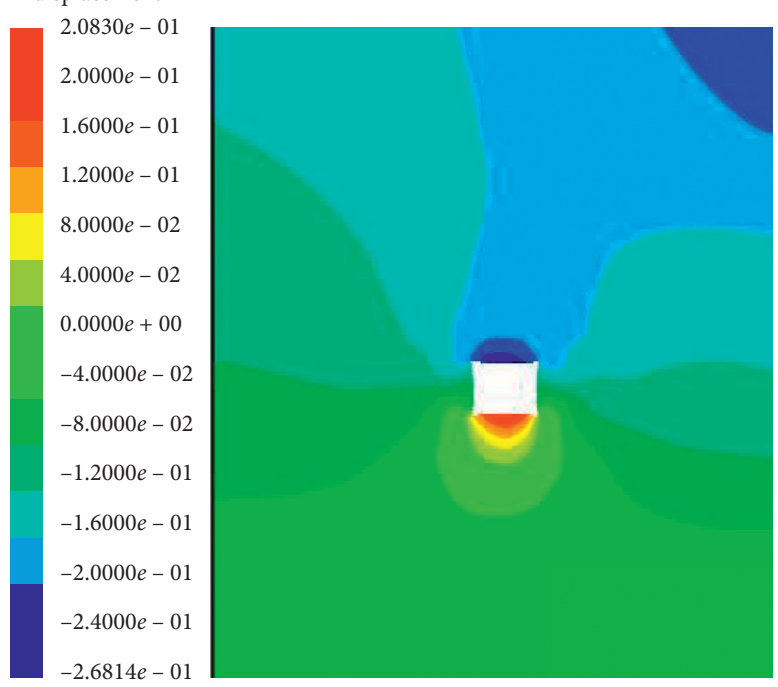

(c)
Contour of

Z-displacement
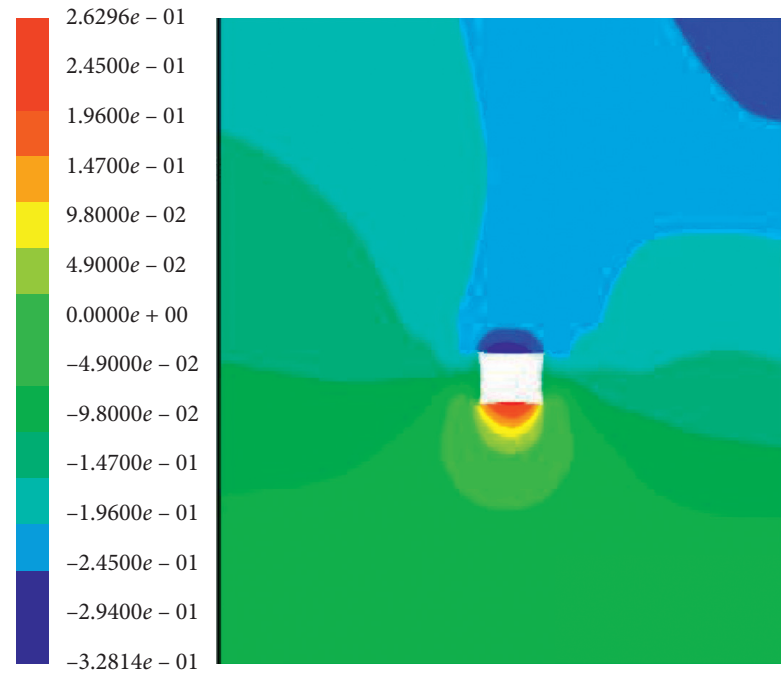

(b)

Contour of

Z-displacement

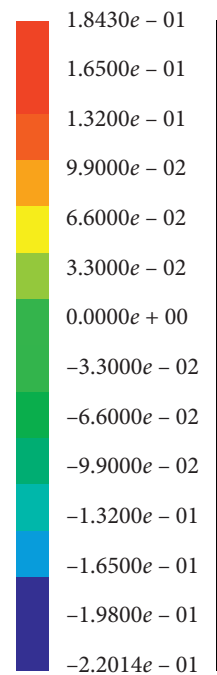

$-2.2014 e-01$

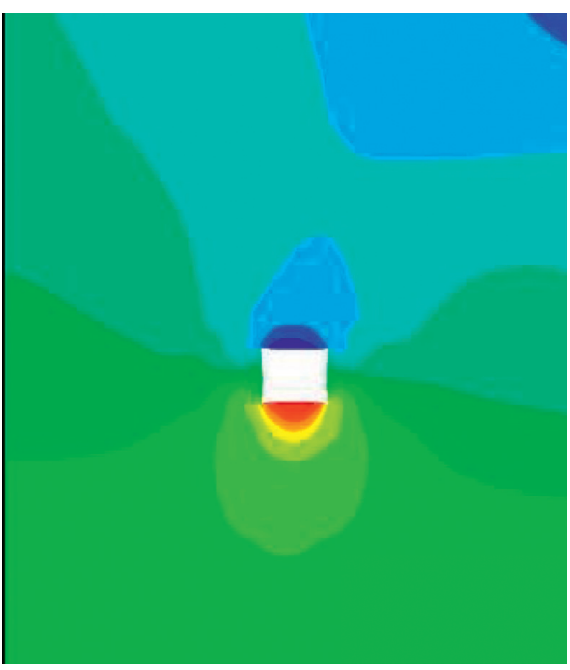

(d)

Figure 11: Deformation of the roof and floor: (a) cutting height $0 \mathrm{~m}$; (b) cutting height $10 \mathrm{~m}$; (c) cutting height $12 \mathrm{~m}$; and (d) cutting height $14 \mathrm{~m}$. 


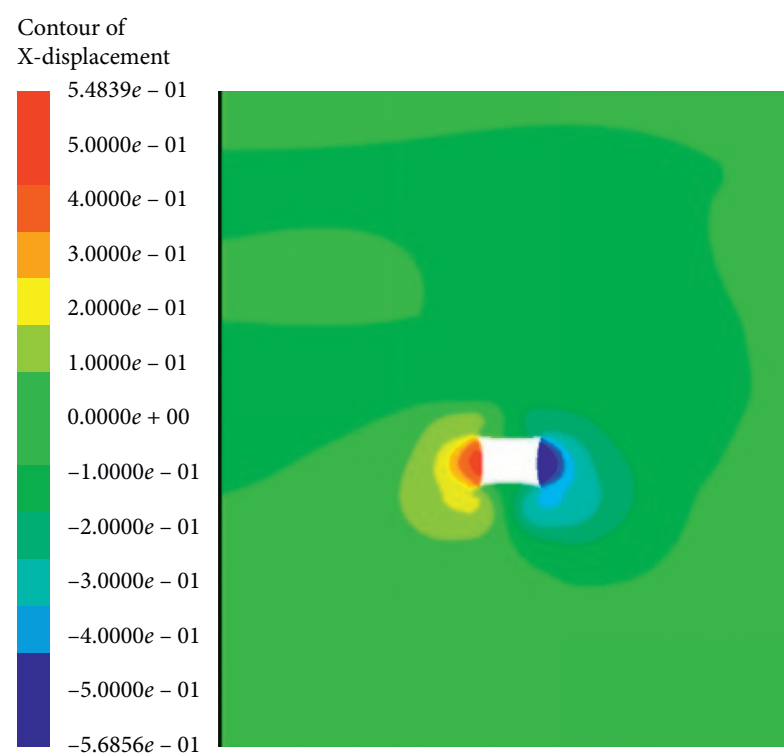

(a)

Contour of X-displacement

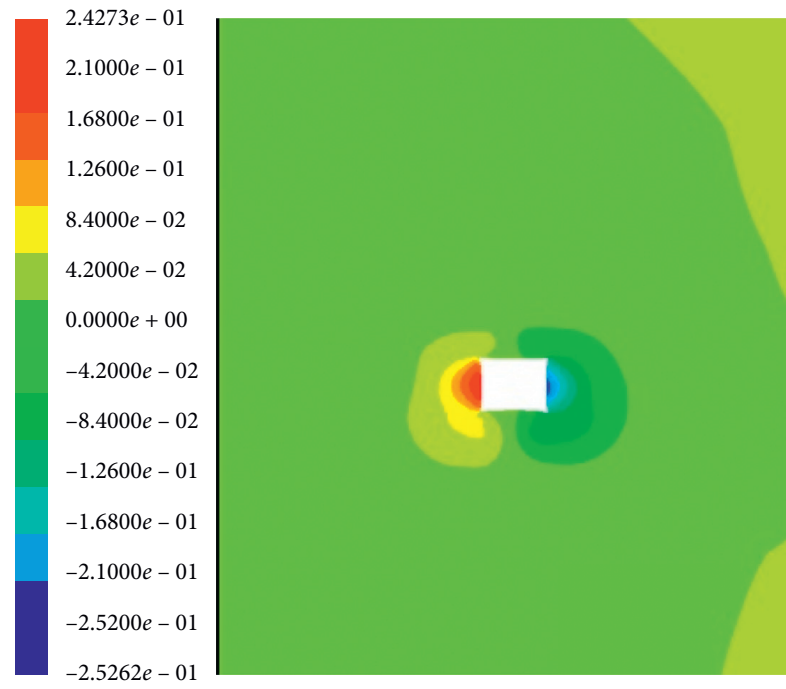

(c)
Contour of

$\mathrm{X}$-displacement
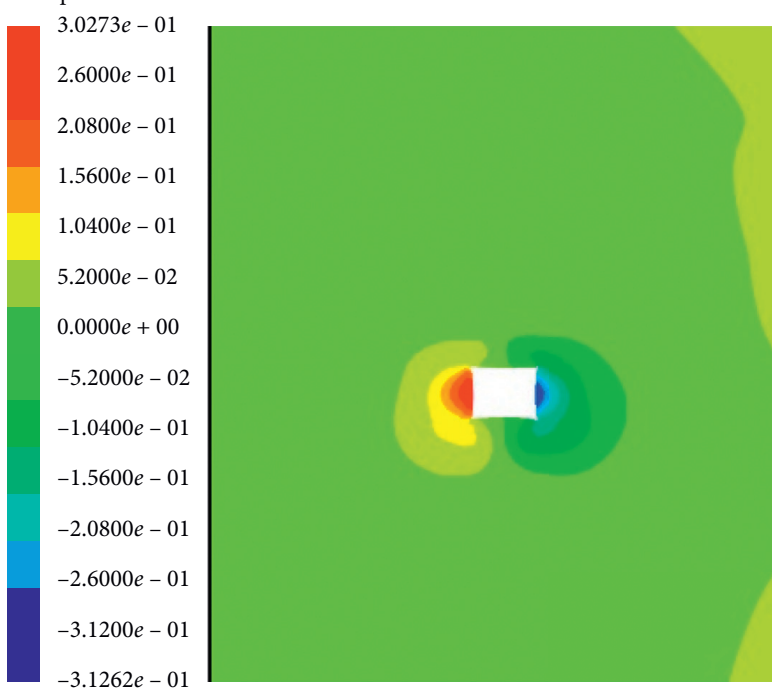

(b)

Contour of X-displacement

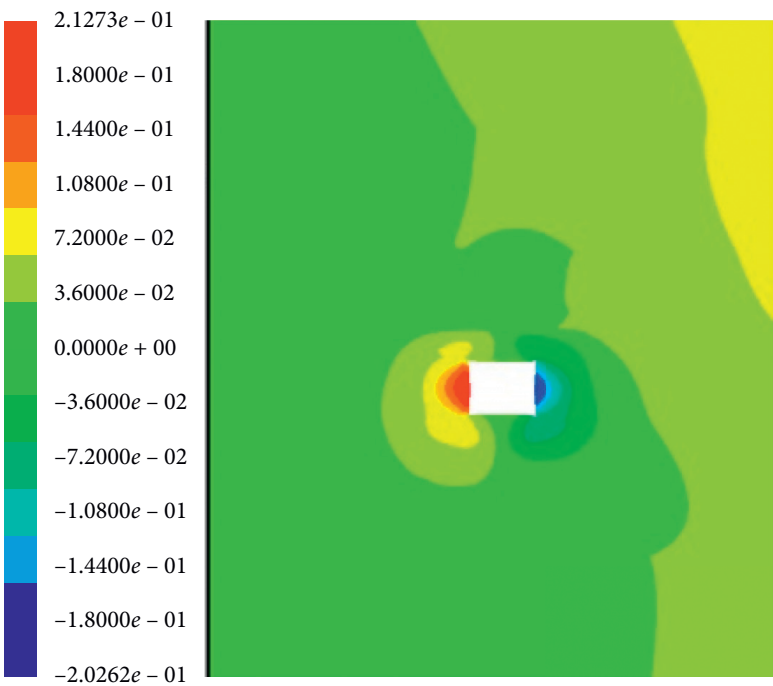

(d)

Figure 12: Deformation of the coal wall: (a) cutting height $0 \mathrm{~m}$; (b) cutting height $10 \mathrm{~m}$; (c) cutting height $12 \mathrm{~m}$; and (d) cutting height $14 \mathrm{~m}$.

TABLE 5: Deformation and stress of the roadway with different roof cutting heights.

\begin{tabular}{lcccccc}
\hline $\begin{array}{l}\text { Cutting height } \\
(\mathrm{m})\end{array}$ & $\begin{array}{c}\text { Peak stress } \\
(\mathrm{MPa})\end{array}$ & $\begin{array}{c}\text { Left deformation } \\
(\mathrm{mm})\end{array}$ & $\begin{array}{c}\text { Right deformation } \\
(\mathrm{mm})\end{array}$ & $\begin{array}{c}\text { Roof subsidence } \\
(\mathrm{mm})\end{array}$ & $\begin{array}{c}\text { Floor heave } \\
(\mathrm{mm})\end{array}$ & $\begin{array}{c}\text { Stress } \\
\text { concentration }\end{array}$ \\
\hline 0 & 58.06 & 548 & 569 & 579 & 549 & Obvious \\
10 & 48.99 & 303 & 313 & 328 & 263 & Slightly obvious \\
12 & 46.80 & 243 & 253 & 268 & 208 & Slightly obvious \\
14 & 39.00 & 213 & 203 & 220 & Not obvious \\
\hline
\end{tabular}

concentration area appeared on the left side of the roadway, which caused the deformation of the left side of the roadway and accelerated the instability and destruction of the roadway.

In Figure 10(b), the numerical calculation showed that when the cutting height was $10 \mathrm{~m}$, the stress caused by the subsidence of the side roof of the gob can be cut off effectively. However, the movement of the overlying strata led to stress concentration in the coal pillar area, and the maximum compressive stress reached $48.99 \mathrm{MPa}$. When the cutting height was $12 \mathrm{~m}$, the stress concentration decreased obviously and the peak stress decreased. The maximum 


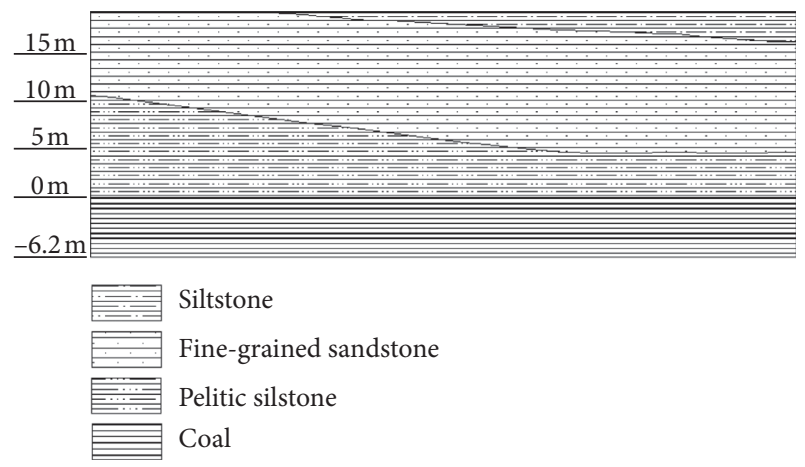

FIgURE 13: Stratigraphic change.

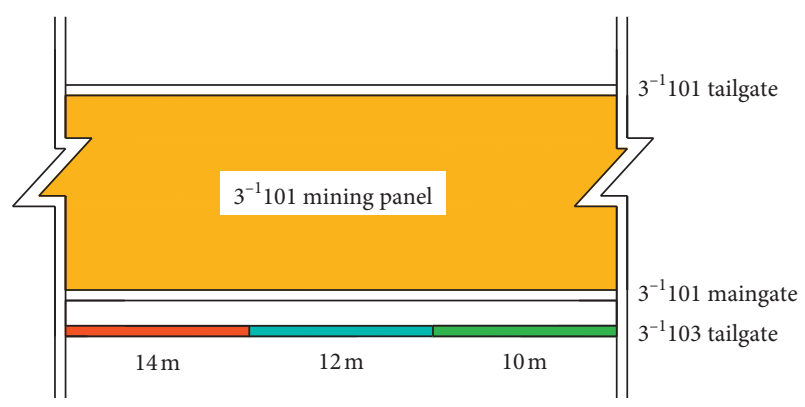

FIGURE 14: Roof cutting zone of the test section.

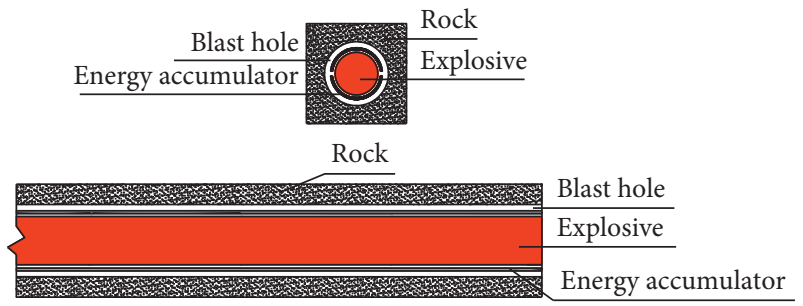

Figure 15: Chart of the explosive structure.

compressive stress was $46.8 \mathrm{MPa}$, as shown in Figure 10(c). When the cutting height was $14 \mathrm{~m}$, the cutting seam cut off the stress transfer on the side of the gob. There was no obvious phenomenon of stress concentration in the coal pillar area. Except for the slightly larger stress near the gob side and the roadway side, the coal pillar was uniformly compressed and the compressive stress was less than $40 \mathrm{MPa}$, as shown in Figure 10(d).

4.2.2. Deformation of the Surrounding Rock. The deformation of the roof, floor, and coal wall (two sides) are as shown in Figures 11 and 12. Without cutting roof, the surrounding rock was seriously deformed under the influence of mining activities. The deformation of each part of the roadway was basically the same, exceeding $540 \mathrm{~mm}$. The deformation of the roadway decreased obviously when the cutting height was $10 \mathrm{~m}$. Among them, the deformation of the floor heave was $263 \mathrm{~mm}$, the subsidence of roof was $328 \mathrm{~mm}$, and the deformation of coal wall could reach $300 \mathrm{~mm}$. Compared with the case without roof cutting, the deformation of the surrounding rock decreased by nearly $50 \%$. The cutting roof controlled the deformation of the surrounding rock to a certain extent. When the cutting height was $12 \mathrm{~m}$, the deformation of the surrounding rock further decreased. The deformation of the floor heave, roof subsidence, and coal wall (two sides) were $208 \mathrm{~mm}, 268 \mathrm{~mm}, 243 \mathrm{~mm}$, and $253 \mathrm{~mm}$, respectively. When the cutting height was $14 \mathrm{~m}$, the deformation of the surrounding rock was the smallest. In this case, the deformation of the floor heave, roof subsidence, and coal wall (two sides) were $184 \mathrm{~mm}, 220 \mathrm{~mm}, 213 \mathrm{~mm}$, and $203 \mathrm{~mm}$, respectively.

The deformation and stress of the roadway under the cutting height $(0 \mathrm{~m}, 10 \mathrm{~m}, 12 \mathrm{~m}$, and $14 \mathrm{~m})$ were sorted out. As shown in Table 5, the deformation of the roadway showed a decreasing trend, and the stress concentration gradually changed from "obvious" to "not obvious." With the increase in the cutting height from $10 \mathrm{~m}$ to $14 \mathrm{~m}$, the four indexes of roadway deformation had obviously decreased with an average decrease of $97 \mathrm{~mm}$.

\section{Engineering Application}

The $300 \mathrm{~m}$ roadway in the $3^{-1} 103$ tailgate was selected as the test section. According to the changing trend of strata in the test section (in Figure 13), the $300 \mathrm{~m}$ test section was designed as three sections along the working face. Also, each section was $100 \mathrm{~m}$. Three schemes were set up with the cutting depth $(14 \mathrm{~m}, 12 \mathrm{~m}$, and $10 \mathrm{~m})$. The zone of the roof cutting section is shown in Figure 14.

Class 2 emulsion explosive for mine was used in blasting. The explosive was $35 \mathrm{~mm}$ in diameter, and the length was $300 \mathrm{~mm}$. The emulsified explosive was installed in the energy gathering device for blasting. The parameters of the energy accumulator were $42 \mathrm{~mm}$ outer diameter, $36.5 \mathrm{~mm}$ inner diameter, and $1500 \mathrm{~mm}$ length. The charge structure is shown in Figure 15.

Firstly, a single-hole blasting test was carried out to determine the reasonable charge quantity and sealing length, and then, interval blasting was carried out. According to roof lithology and engineering experience, the following charge parameters were proposed for testing. Charge structures of three test sections are shown in Table 6 and Figure 16.

After blasting, a CXK6 coal mine blast hole imager was used to peep at the blast hole and observe the cracks. As shown in Figure 17(a), there were obvious crack propagation phenomena in the blast hole, and two main cracks basically penetrated through the blast hole when the peep image was unfolded. Due to blasting, the blast hole was damaged and the local crack width increased. This phenomenon verified the phenomenon of crack zoning in 3.3. After mining the working face, the roof broke along the blast holes, forming the roof cutting structure surface as shown in Figure 17(c).

The surface displacement of the roadway in the test section was monitored to analyze the deformation law of three different schemes (as shown in Figures 18 and 19). The maximum deformation of the roof and floor was $290 \mathrm{~mm}$, $268 \mathrm{~mm}$, and $232 \mathrm{~mm}$ when the cutting height was $10 \mathrm{~m}$, $12 \mathrm{~m}$, and $14 \mathrm{~m}$. The deformation of the roof and floor was 
TABLE 6: Charge parameters of each test section.

\begin{tabular}{lcccc}
\hline Test section & Charge quantity (volume) & Charge structure & Energy accumulator & Sealing length (m) \\
\hline 1 & 21 & $3+3+3+3+3+3+2+1$ & 8 & 3 \\
2 & 15 & $3+3+3+3+2+1$ & 6 & 3 \\
3 & 12 & $3+3+3+2+1$ & 5 & 3 \\
\hline
\end{tabular}

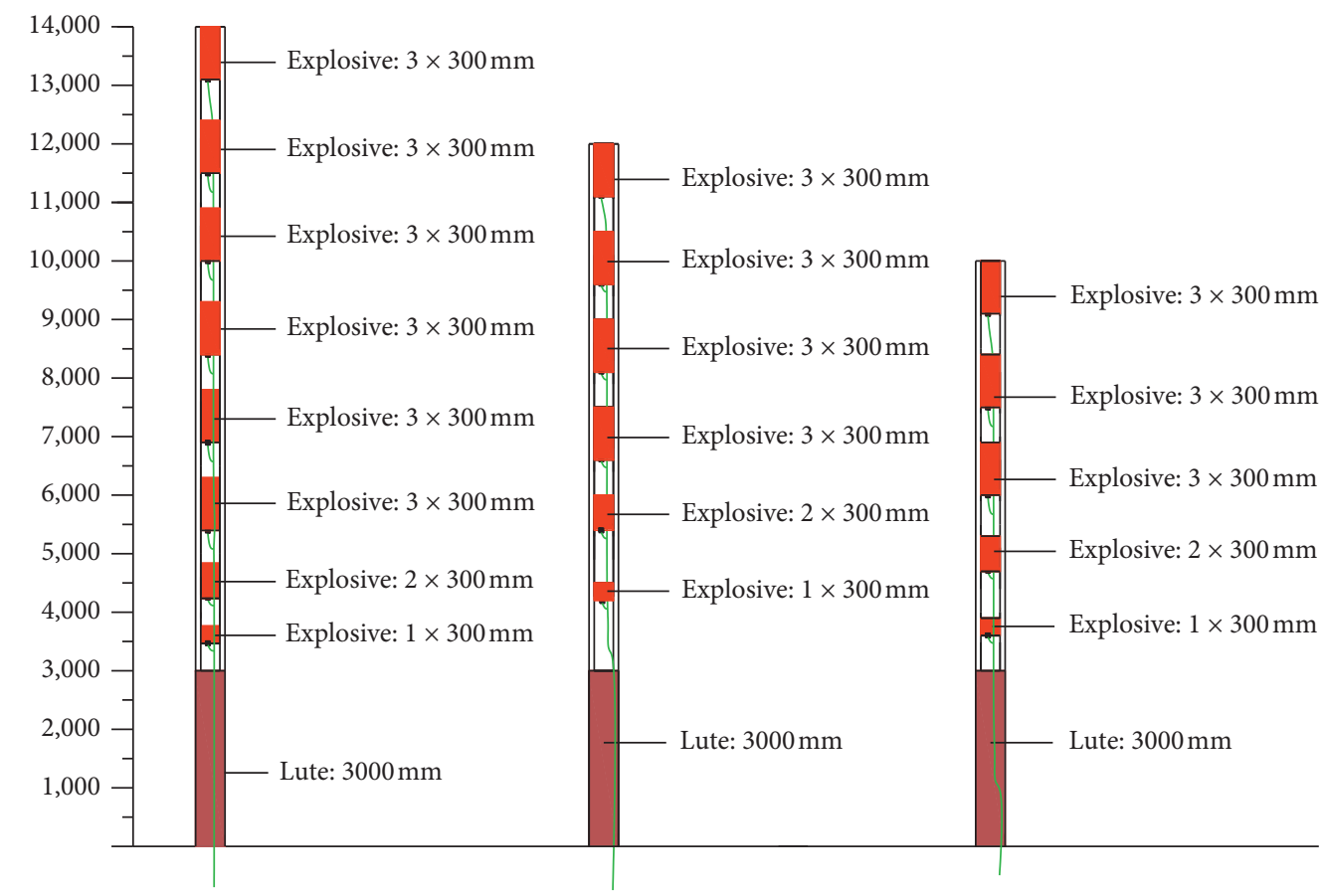

FIgURE 16: Charge structure chart of blast holes.

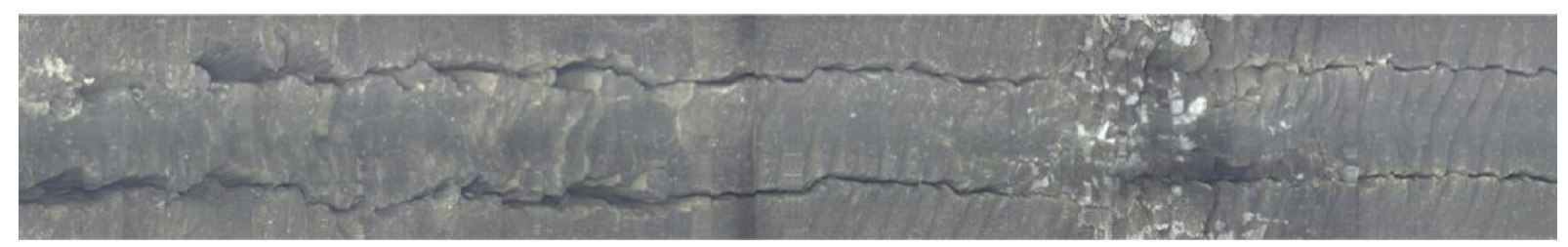

(a)

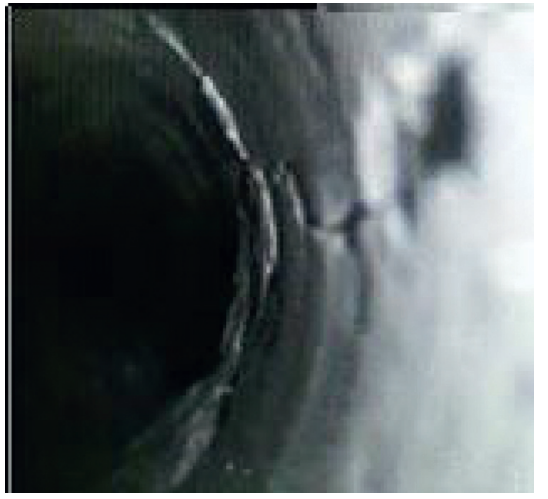

(b)

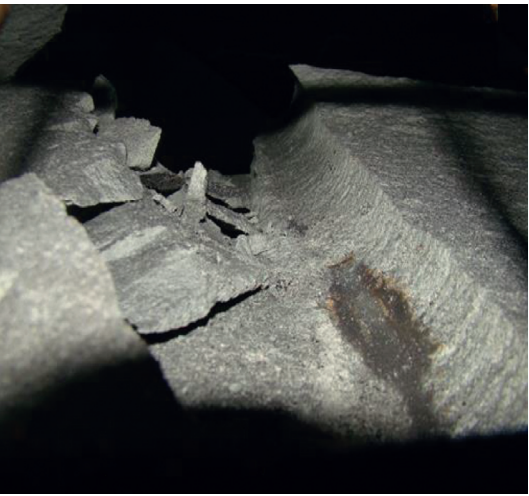

(c)

FIGURE 17: Blast hole cracks: (a) two main cracks; (b) endoscopic view; and (c) blast hole structural plane. 


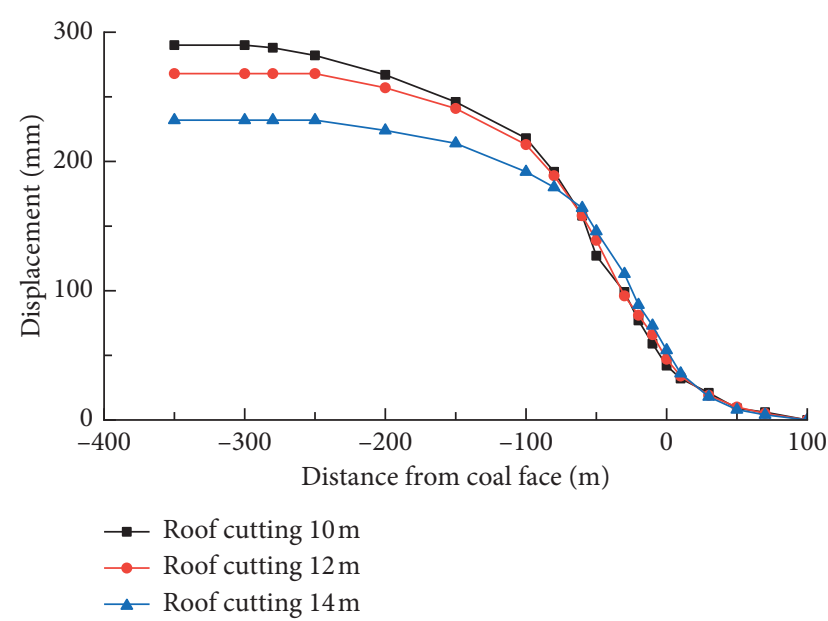

FIGURE 18: Deformation of the roof and floor of the roadway.

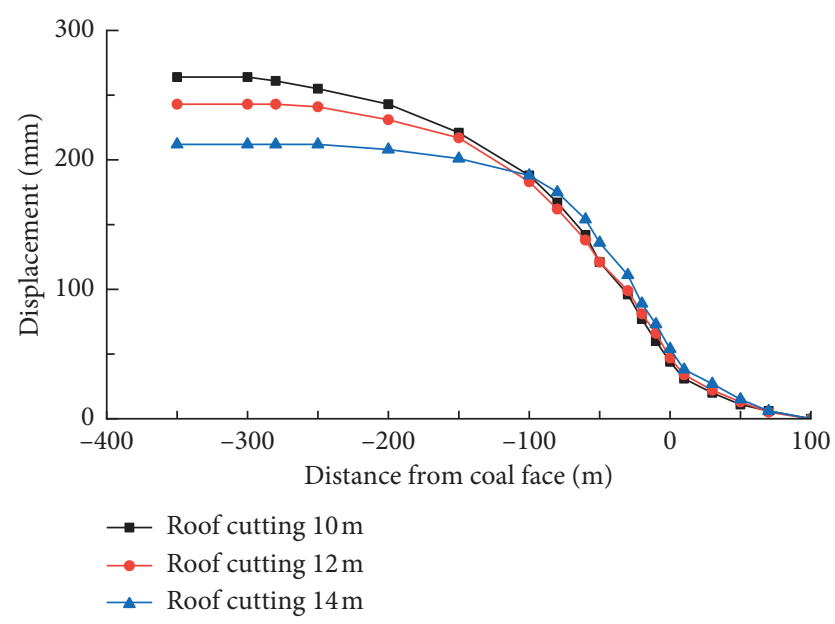

FIGURE 19: Deformation of two sides of the roadway.

inversely proportional to the cutting height. Similarly, the deformation of two sides of the roadway was $264 \mathrm{~mm}$, $243 \mathrm{~mm}$, and $212 \mathrm{~mm}$, respectively, when the cutting height was $10 \mathrm{~m}, 12 \mathrm{~m}$, and $14 \mathrm{~m}$. It can be concluded that the higher the cutting height was, the more preferential the roadway was to reach the stable state. Cutting the roof by directional charge blasting could change the surrounding rock structure and cut off the stress transmission path. Thus, the roof cutting and pressure relief can control the deformation of the roadway and protect the roadway.

\section{Conclusions}

In this paper, the deformation mechanism and surrounding rock control measures of a deep buried high-stress roadway in the Hongqinghe coal mine were studied, and the numerical simulation and engineering test were carried out. The main conclusions are as follows.

Through field observation and measurement, affected by the in situ stress fluctuation, the $3^{-1} 103$ tailgate was in a complex stress environment. The maximum stress reached $20 \mathrm{MPa}$. The integrity of the coal wall was poor, cracks appeared, and expansion occurred in the middle of the roadway. Secondary surrounding rock deformation occurred in the $3^{-1} 103$ tailgate due to mining activity in the $3^{-1} 101$ mining panel. The roadway floor was warped and cracked, and the bolt was broken. According to the deformation law of surrounding rock, the roadway was divided into three areas: the initial deformation zone, serious deformation zone, and deformation stability zone.

The numerical calculation model of directional blasting roof cutting technology was established, while the crack propagation and stress distribution of the surrounding rock at different time periods were obtained. Rock failure can be divided into three stages: initial crack formation of the blast hole, expansion of the failure zone, and directional crack extension. Finally, the cracks between adjacent blast holes penetrated to achieve a directional fracture effect at 164 us. According to the failure and crack propagation of the blast holes in the numerical calculation, the rock was divided into a blast hole damage zone, crack penetration zone, and unilateral crack growth zone.

According to the engineering geological conditions, the numerical model of roof cutting of a deep buried high-stress roadway was established, and the stress distribution and surrounding rock deformation of the roadway under different roof cutting heights were obtained. When the cutting height was $14 \mathrm{~m}$, the cutting seam cuts off the stress transfer on the side of the gob. There was no obvious phenomenon of stress concentration in the coal pillar area, and the compressive stress was less than $40 \mathrm{MPa}$. At this time, the deformation of the floor heave, roof subsidence, and coal wall (two sides) was $184 \mathrm{~mm}, 220 \mathrm{~mm}, 213 \mathrm{~mm}$, and $203 \mathrm{~mm}$, respectively. According to the numerical results, the directional blasting roof cutting measures were implemented in the high-stress roadway of the Hongqinghe coal mine. Cutting the roof by shaped charge blasting can change the surrounding rock structure and cut off the stress transmission path. Thus, the roof cutting and pressure relief can control the deformation of the roadway and protect the roadway.

\section{Data Availability}

The raw/processed data required to reproduce these findings cannot be shared at this time as the data also form part of an ongoing study.

\section{Conflicts of Interest}

The authors declare no conflicts of interest.

\section{Authors' Contributions}

Chenkang Liu and Xiaojie Yang were responsible for conceptualization of the study; Chenkang Liu was responsible for the methodology; Chenkang Liu and Yuguo Ji were responsible for software; Chenkang Liu and Songlin Yue performed the formal analysis; Chenkang Liu and Xingyu Zhang investigated the study; Chenkang Liu and Lin Hou involved in data curation; and English editing was carried 
out by Chenkang Liu and Honglei Sun. Xiaojie Yang and Chenkang Liu contributed equally to this work.

\section{Acknowledgments}

This work was conducted with support from the National Natural Science Foundation of China (grant no. 41672347). The authors also acknowledge the support of the Inner Mongolia Yitai Group Co., Ltd.

\section{References}

[1] P. Horyl and R. Šňupárek, "Reinforcing measures of steel roadway support in rockburst prone areas/Wzmacnianie stalowych obudów chodnikowych w obszarach zagrożonych tạpnięciami," Archives of Mining Sciences, vol. 57, no. 1, pp. 193-208, 2012.

[2] Z.-y. Wang, L.-m. Dou, and G.-f. Wang, "Mechanism analysis of roadway rockbursts induced by dynamic mining loading and its application," Energies, vol. 11, no. 9, pp. 2313-2336, 2018.

[3] M. C. He, H. P. Xie, S. P. Peng, and Y. D. Jiang, "Study on rock mechanics in deep mining engineering," Chinese Journal of Rock Mechanics and Engineering, vol. 24, no. 16, pp. 28032813, 2005.

[4] T. Li, R.-l. Shan, H.-s. Han, W.-h. Yang, and N. Liu, "Mechanical mechanism and support design analysis on boltbeam-net support in soft rock roadway in Qigou coal mine," Journal of Coal Science and Engineering (China), vol. 18, no. 3, pp. 247-253, 2012.

[5] H. Zhang, A. C. Adoko, Z. Meng, H. Wang, and Y. Jiao, "Mechanism of the mudstone tunnel failures induced by expansive clay minerals," Geotechnical and Geological Engineering, vol. 35, no. 1, pp. 263-275, 2017.

[6] Y. X. Hao, J. Wang, Y. Yuan, X. L. Wang, G. L. Zhu, and M. C. He, "Large deformation control technology for expansive and weak-cemented soft rock roadways in Shajihai coal mine," Journal of Mining \& Safety Engineering, vol. 133, no. 4, pp. 684-691, 2016.

[7] X. J. Yang, J. W. Pang, and H. P. Lou, "Deformation mechanical mechanism of strongly swelling floor heave in the soft rock roadway of Ting nan coal mine," Journal of China Coal Society, vol. 40, no. 8, pp. 1761-1767, 2015.

[8] M. Y. Wang, H. Song, D. L. Zheng, and S. L. Chen, "On mechanical of zonal disintegration within rock mass around deep tunnel and definition of "deep rock engineering"” Chinese Journal of Rock Mechanics and Engineering, vol. 25, no. 9, pp. 1771-1776, 2006.

[9] Y. Yuan, W. J. Wang, C. Yuan, W. J. Yu, H. Wu, and W. Q. Peng, "Large deformation failure mechanism of surrounding rock for gateroad under dynamic pressure in deep coal mine," Journal of China Coal Society, vol. 41, no. 12, pp. 2940-2950, 2016.

[10] S. Y. Chen, C. S. Song, Z. B. Guo, J. Wang, and Y. Wang, "Asymmetric deformation mechanical mechanism and control countermeasure for deep roadway affected by mining," Journal of China Coal Society, vol. 41, no. 1, pp. 246-254, 2016.

[11] Q. Wang, B. Jiang, R. Pan et al., "Failure mechanism of surrounding rock with high stress and confined concrete support system," International Journal of Rock Mechanics and Mining Sciences, vol. 102, no. 1, pp. 89-100, 2018.

[12] X. J. Yang, C. W. Hu, J. H. Liang, Y. B. Zhou, G. F. Ni, and R. F. Huang, "A case study on the control of large deformations in a roadway located in the Du'erping coal mine in
China," Advances in Materials Science and Engineering, vol. 2019, Article ID 9628142, 13 pages, 2019.

[13] Z. B. Guo, L. Zhang, H. H. Wang, S. Y. Yin, T. Li, and X. H. Kuai, "Failure mechanism of bolts and countermeasures in swelling soft rock support," Tehnicki Vjesnik-Technical Gazette, vol. 25, no. 5, pp. 1447-1456, 2018.

[14] X. Yang, E. Wang, Y. Wang, Y. Gao, and P. Wang, "A study of the large deformation mechanism and control techniques for deep soft rock roadways," Sustainability, vol. 10, no. 4, pp. 1100-1119, 2018.

[15] R. Yang, Q. Li, Q. Li, and X. Zhu, "Assessment of bearing capacity and stiffness in new steel sets used for roadway support in coal mines," Energies, vol. 10, no. 10, pp. 1581-1596, 2017.

[16] W. Mu, L. Li, Z. Guo, Z. Du, and S. Wang, "Novel segmented roadside plugging-filling mining method and overlying rock mechanical mechanism analyses," Energies, vol. 12, no. 11, pp. 2073-2092, 2019.

[17] Y. Chen, S. Ma, Y. Yang, N. Meng, and J. Bai, "Application of shallow-hole blasting in improving the stability of gob-side retaining entry in deep mines: a case study," Energies, vol. 12, no. 19, pp. 3623-3638, 2019.

[18] H. G. Qi, "Research and practice on integrated pressure releasing technology in deep coal mine rock roadway under high stress," Journal of Mining \& Safety Engineering, vol. 33, no. 6, pp. 1023-1029, 2016.

[19] M. He, G. Zhu, and Z. Guo, "Longwall mining "cutting cantilever beam theory" and 110 mining method in China-the third mining science innovation," Journal of Rock Mechanics and Geotechnical Engineering, vol. 7, no. 5, pp. 483-492, 2015.

[20] G. F. Zhang, M. C. He, X. P. Yu, and Z. G. Huang, "Research on the technique of no-pillar mining with gob-side entry formed by advanced roof caving in the protective seam in Baijiao coal mine," Journal of Mining \& Safety Engineering, vol. 28, no. 4, pp. 511-516, 2011.

[21] M. C. He, Z. Q. Song, A. Wang, H. H. Yang, and H. G. Qi, "Theory of longwall mining by using roof cutting shortwall team and 110 method," Coal Science and Technology Magazine, vol. 1, no. 1, pp. 1-9, 2017.

[22] J. Hu, M. He, J. Wang, Z. Ma, Y. Wang, and X. Zhang, "Key parameters of roof cutting of gob-side entry retaining in a deep inclined thick coal seam with hard roof," Energies, vol. 12, no. 5, pp. 934-952, 2019.

[23] Z. Ma, J. Wang, M. He, Y. Gao, J. Hu, and Q. Wang, "Key technologies and application test of an innovative noncoal pillar mining approach: a case study," Energies, vol. 11, no. 10, pp. 2853-2874, 2018.

[24] X. Ma, M. He, J. Sun, H. Wang, X. Liu, and E. Zhen, "Neural network of roof cutting blasting parameters based on mines with different roof conditions," Energies, vol. 11, no. 12, pp. 3468-3489, 2018.

[25] X. J. Yang, C. W. Hu, M. C. He et al., "Study on presplitting blasting the roof strata of adjacent roadway to control roadway deformation," Shock and Vibration, vol. 2019, p. 16, 2019.

[26] Q. Wang, M. He, J. Yang, H. Gao, B. Jiang, and H. Yu, "Study of a no-pillar mining technique with automatically formed gob-side entry retaining for longwall mining in coal mines," International Journal of Rock Mechanics and Mining Sciences, vol. 110, no. 7, pp. 1-8, 2018.

[27] Y. Wang, J. Yang, M. He et al., "Test of a liquid directional roof-cutting technology for pressure-relief entry retaining mining," Journal of Geophysics and Engineering, vol. 16, no. 3, pp. 620-638, 2019. 
[28] X. Yang, C. Liu, Y. Ji, X. Zhang, and S. Wang, "Research on roof cutting and pressure releasing technology of directional fracture blasting in dynamic pressure roadway," Geotechnical and Geological Engineering, vol. 37, no. 3, pp. 1555-1567, 2019.

[29] Q. Wang, Z. Jiang, B. Jiang, H. Gao, Y. Huang, and P. Zhang, "Research on an automatic roadway formation method in deep mining areas by roof cutting with high-strength boltgrouting," International Journal of Rock Mechanics and Mining Sciences, vol. 128, Article ID 104264, 2020.

[30] G. F. Zhang, P. P. Miao, E. Y. Wang, and X. Chen, "Research on roof fracture criterion and moving rule of gob-side entry in shallow seam," Journal of Mining Science and Technology, vol. 2, no. 2, pp. 109-119, 2017.

[31] M. G. Qian, X. X. Miao, and J. L. Xu, "Theoretical study of key stratum ground control," Journal of China Coal Society, vol. 21, no. 3, pp. 225-230, 1996.

[32] J. L. Xu and M. G. Qian, "Method to distinguish key strata in overburden," Journal of China University of Mining \& Technology, vol. 29, no. 5, pp. 463-467, 2000.

[33] X. Yang, E. Wang, X. Ma, G. Zhang, R. Huang, and H. Lou, "A case study on optimization and control techniques for entry stability in non-pillar longwall mining," Energies, vol. 12, no. 3, pp. 391-407, 2019.

[34] J. Yang, M. He, and C. Cao, "Design principles and key technologies of gob side entry retaining by roof pre-fracturing," Tunnelling and Underground Space Technology, vol. 90, pp. 309-318, 2019.

[35] Y. Gao, Y. Wang, J. Yang, X. Zhang, and M. He, "Meso- and macroeffects of roof split blasting on the stability of gateroad surroundings in an innovative nonpillar mining method," Tunnelling and Underground Space Technology, vol. 90, pp. 99-118, 2019.

[36] W. W. Ma, The Analysis of Rock Dynamic Mechanical Properties and Rock Breaking Process in Tunnel Blasting Excavation, AnHui University of Science and Technology, Huainan, China.

[37] Z. Tao, Z. Song, M. He, Z. Meng, and S. Pang, "Principles of the roof cut short-arm beam mining method (110 method) and its mining-induced stress distribution," International Journal of Mining Science and Technology, vol. 28, no. 3, pp. 391-396, 2018.

[38] Z. B. Guo, J. Wang, T. P. Cao, L. Chen, and J. Wang, "Research on key parameters of gob-side entry retaining automatically formed by roof cutting and pressure release in thin coal seam mining," Journal of China University of Mining \& Technology, vol. 45, no. 5, pp. 879-885, 2016.

[39] M. He, Y. Gao, J. Yang, and W. Gong, "An innovative approach for gob-side entry retaining in thick coal seam longwall mining," Energies, vol. 10, no. 11, pp. 1785-1806, 2017. 